\title{
FACTORS CAUSING VARIATION IN THE HAMOGLOBIN LEVEL WITH AGE IN THE FIRST YEAR OF LIFE
}

\author{
BY
}

HELEN M. M. MACKAY, M.D., M.R.C.P.

(From the Queen's Hospital for Children and the Mothers' Hospital, London.)

The hæmoglobin level of infants during the first year of life usually shows certain clearly marked phases. These are:-a sharp drop from the high level at birth to a figure in the neighbourhood of half this value by the third month of life; a rise from this age till the sixth month of life; a second fairly steady fall continuing until after mixed feeding has been started, and then a slow and rather irregular rise ${ }^{19}$. It is the purpose of this paper, by bringing together our own results and those of other investigators, to show, or suggest, a sequence of causes producing these changes in hæmoglobin level. Many of the conclusions reached, however, must at present be regarded as tentative.

Average curve for first year.--First let us consider in greater detail the ordinary hæmoglobin curve for the first year of life for a breast-fed baby (Graph I). The absolute hæmoglobin values are of minor importance for our present purpose, since they may vary greatly in individuals as well as with different technique for estimation, but changes in level occur at similar ages in nearly all babies and it is on these we now wish to concentrate*.

At birth the hæmoglobin percentage averages, according to our data, about 146; it then drops rapidly, especially during the first week of life, so that by one week old it reaches 131, and ky 2 to 3 months old 73 . For the next three months it is usually rising, reaching an average level of 78 at 5 to 6 months old. Then it drops slowly till it reaches 73 at 10 to 11 months. It should be noted that these figures are average values, and consequently do not show the magnitude of the rise and fall in level commonly met in individuals. For example, the rise (without treatment) between about the third month and the sixth month of life is fairly frequently 15 per cent., and may be over 25 per cent. (Graph I, Cases 1-4; Graph II, Case 6); but because of the varying ages at which the rise begins and ends (or in other words the varying ages at which the highest and lowest levels occur in different individuals), its extent is masked by taking an average figure for each month of life. These figures refer to breast-fed babies without any infections.

* All figures for the author's cases quoted in this paper are in terms of the PriceJones-Haldane hæmoglobinometer standard. The calculation of figures based on this standard from those we have previously published is discussed in a preceding paper $^{20}$. 
Artificially fed babies show a similar type of hæmoglobin curve, but the average figures are slightly lower.

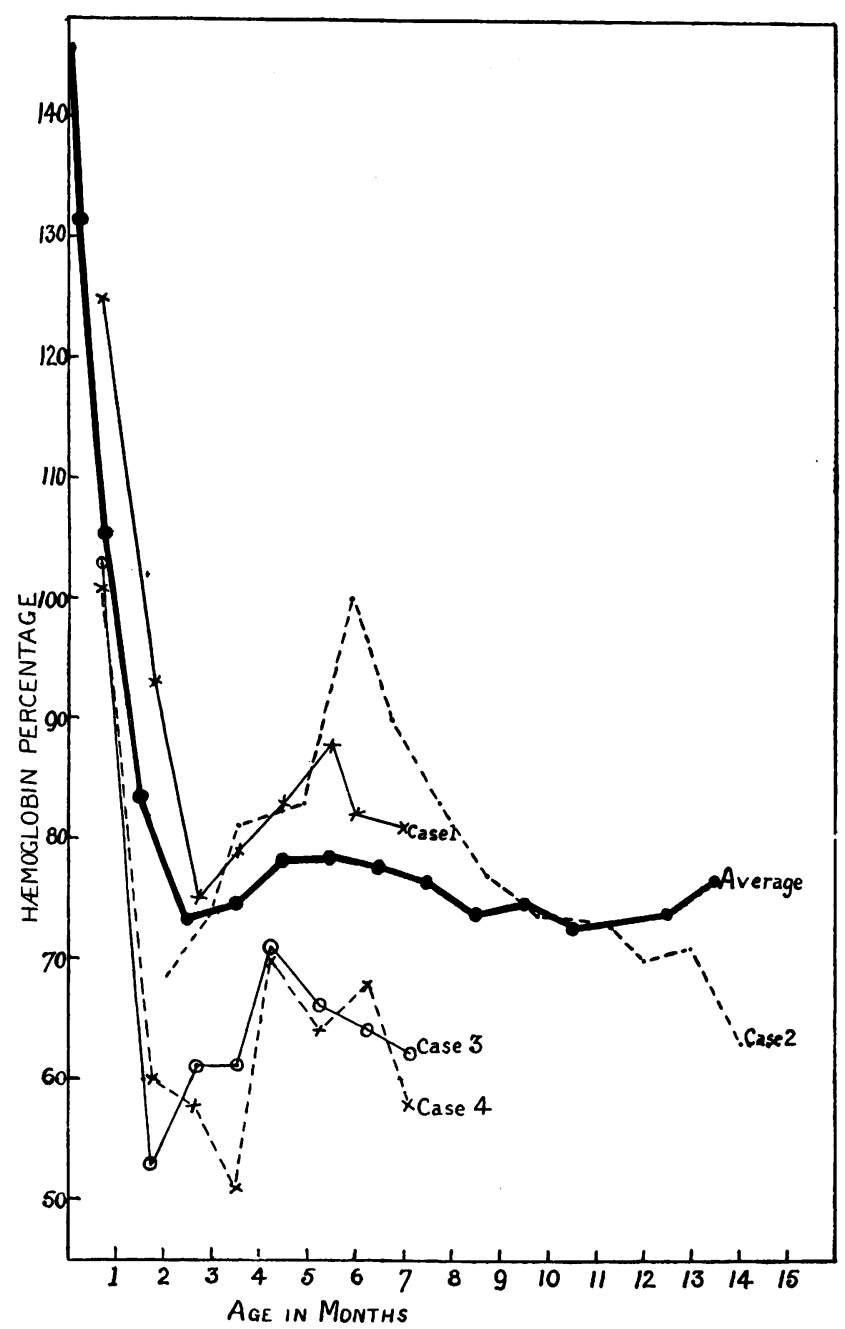

GraPH I.-Average hæmoglobin curve for breast-fed babies for the first year of life, with curves from untreated infants (Cases 1-4).

CASE 1.-A full-term baby showing a drop of $50 \%$ between $\frac{3}{4}$ and $2 \frac{3}{4}$ months old; a rise of $13 \%$ between $2 \frac{3}{4}$ and $5 \frac{1}{2}$ months; and a subsequent fall. A typical case, excepting that at $\frac{3}{4}$ month the level was higher than usual.

CASE 2.-A full-term baby showing a rise of $32 \%$ between 2 and 6 months of age, and a drop of $37 \%$ between 6 and 14 months. In this case both rise and fall were considerably greater in extent than usual.

CASE 3.-A twin weighing $4 \mathrm{lb} .11 \mathrm{oz}$. at birth, and with a hæmoglobin level always below the curve for the average, but rising by $18 \%$ between $1 \frac{3}{4}$ and $4 \frac{1}{4}$ months

Case 4.-Twin to Case 3., weighing $3 \mathrm{lb} .13 \mathrm{oz}$. at birth, and tending to have a hæmoglobin level rather lower than his brother who was heavier at birth. He shows a rise of $19 \%$ in 3 weeks, reaching $70 \%$ at $4 \frac{1}{4}$ months. 
Any severe infection is likely to lower the hæmoglobin level; the type of anæmia thereby produced appears as a rule to be hæmolytic ${ }^{14}$, i.e., an anæmia due to increased blood destruction. On recovery from the infection there is a tendency to spontaneous improvement in the hæmoglobin level, provided other factors are favourable. It seems that the existence of an infection may postpone the rise in hæmoglobin level which generally occurs in the second three months of life.

The average level at birth and variation with birth weight.-Our average percentage figure for hæmoglobin level at birth of healthy infants is approximately 146, with a maximum value of 179 and a minimum value of 110. If we group the babies by birth weight (Table 1), the 5-lb. babies

TABLE 1.

BIRTH WEIGHT AND HAMOgLOBIN IN FIRST WEEK.

\begin{tabular}{|c|c|c|c|c|c|}
\hline \multirow{2}{*}{ Birth weight. } & \multicolumn{4}{|c|}{ Average hæmoglobin percentage. } & \multirow{2}{*}{$\begin{array}{l}\text { Drop in first } \\
\text { week. }\end{array}$} \\
\hline & \multicolumn{2}{|c|}{ Under 24 hours. } & \multicolumn{2}{|c|}{ 8th day. } & \\
\hline 5 lb. odd & $158 \cdot 5$ & (12) & $137 \cdot 7$ & (10) & $20 \cdot 8$ \\
\hline 6 lb. , , & $148 \cdot 2$ & (14) & $128 \cdot 0$ & (13) & $20 \cdot 2$ \\
\hline 7 lb. ,, & $141 \cdot 0$ & (22) & $129 \cdot 4$ & (20) & $11 \cdot 6$ \\
\hline $8 \mathrm{lb}$. and over & $139 \cdot 8$ & (14) & $133 \cdot 0$ & (12) & $6 \cdot 8$ \\
\hline $\begin{array}{l}5-9 \text { lb. combined ... } \\
6 \mathrm{lb} \text {. and upwards }\end{array}$ & $145 \cdot 7$ & (62) & $131 \cdot 4$ & (55) & $14 \cdot 3$ \\
\hline combined $\quad$... & $142 \cdot 7$ & (50) & $129 \cdot 9$ & (45) & $12 \cdot 8$ \\
\hline
\end{tabular}

Figures in brackets indicate the number of healthy babies examined.

average 158.5, and there is a serial drop in hæmoglobin level with increasing weight until we reach the babies of $8 \mathrm{lb}$. and upwards who average $139 \cdot 8$, or about 19 per cent. lower.

These figures suggest that each pound increase in birth weight is accompanied by a corresponding decrease in the average hæmoglobin level. Roughly speaking, the higher the birth weight the lower the average hæmoglobin level at birth and vice versa, though individuals vary widely. Unfortunately we have no figures for the average hæmoglobin level at birth of babies weighing under $5 \mathrm{lb}$., and although various authors ${ }^{2}$ have stated that the hæmoglobin level at birth of premature babies is higher than in full term infants, we have not been able to discover any entirely satisfactory comparative figures.

CaUse of this variation.-Table 1 shows the new-born babies in our series arranged in groups of similar birth weight. Since all the babies were healthy infants in one maternity hospital, it seems legitimate to assume that the higher the birth weight the greater the average intra-uterine age, or at least the greater the average degree of maturity at birth. If this be so, then the more mature new-born babies have a lower hæmoglobin level than the less mature; so either blood production diminishes or blood destruction increases in late intra-uterine life. Probably both factors play a part.

To consider blood production first:- In the fœtus of 4 to 6 months, the number of immature red cells, e.g., nucleated cells and reticulocytes, is very 
large ${ }^{25}$, and presumably blood formation is rapid to keep pace with the rapid growth of the fotus. The reticulocytes and nucleated cells present in the full term baby at birth, though much in excess of adult figures ${ }^{4,2.5}$, are far fewer than in the young foetus, and considerably fewer than in the premature babies.2. If we assume that the number of reticulocytes in circulation is a rough indication of the rate of blood production, these facts suggest, as might be expected, that the rate of new red-cell formation is slowing down with the diminished rate of growth as the age of the fœtus increases. Nevertheless, there is also evidence to suggest increased blood destruction. In hæmolytic anæmias, as is well known, the bilirubin in the blood is raised as a result of hæmolysis. In the umbilical vein at birth (whether the infant is delivered by the normal passages or by Cæsarian section), the bilirubin is very much higher than in adult blood. Hampson ${ }^{10}$ finds an average of 1 in 75,000 in fœtal blood as compared with 1 in 400,000 in adult blood; and his figures suggest, though the total number of premature infants and fotuses examined was not large, that between 14 weeks' gestation and term the bilirubin in the fœtal blood steadily increases. His figures are:14 weeks fœtus, no bilirubin in blood plasma; 20 weeks fœtus, bilirubin definitely present; 28 weeks, marked positive van den Bergh; 34 weeks, bilirubin 1 in 150,000 ; 36 weeks ( 2 cases), bilirubin 1 in 130,000 and 1 in 120,000 ; 38 weeks, bilirubin 1 in 100,000 ; and at full term, bilirubin 1 in 75,000 . Hence there seems little doubt that during the latter part of pregnancy there is increased fœtal blood destruction. If we assume that the high hæmoglobin level at birth is necessitated by the low oxygen tension of fotal blood, and the drop after birth is in response to a sudden rise in oxygen tension at this time, then it seems legitimate to suppose that the probable explanation of the increased hæmolysis which apparantly occurs during late intra-uterine life is a gradual improvement in the oxygenation of the fœtal blood during this period. Whether there is any anatomical or experimental evidence to support the suggestion the author has not discovered.

Fall in first three months : variation with birth weight.-During the first 6 weeks of life the drop in red cell count and hæmoglobin level is usually rapid. It is generally most rapid in the first week, the average drop for our cases being 14 per cent. by the eighth day. Schiff ${ }^{26}$ in Grosswardein found an average drop of 26 per cent. during the same period; Zibordi ${ }^{31} 17$ per cent.; and Lucas ${ }^{18}$ and his co-workers 14 per cent. The extent of the fall shows wide individual variations: the maximum in our series was 44 per cent. in one week in an apparently normal baby, but, on the other hand, several had at one week old a hæmoglobin level approximately equal to that at birth.

The fall in hæmoglobin level reflects the drop in the red-cell count: Lucas $^{18}$ and his co-workers found in the first week of life a drop of about one million cells, i.e., from 5,511,000 per c.mm. at birth (31 cases) to 4,504,000 (19 cases) on the eighth day. Mayers' ${ }^{23}$ figures indicate in the first two weeks a drop of nearly two million cells: from 7,630,000 at birth (41 cases) to $5,790,000$ (10 cases) on the 14th day. 
The fall in hæmoglobin percentage, with individual exceptions, is usually greater in the smaller babies. In our series in those of $5 \mathrm{lb}$. birth weight it averaged about 21 in the first week; in those of $6 \mathrm{lb} .20$; in those of $7 \mathrm{lb} .12$; and in those of 8 and $9 \mathrm{lb}$. only about $\tau$ (Table 1). By the third month $5 \mathrm{lb}$. babies had dropped by about 90 , and babies of $8 \mathrm{lb}$. and upwards by 66 per cent. (see Tables 2 and 3). The rapid drop shown by small premature babies

TABLE 2.

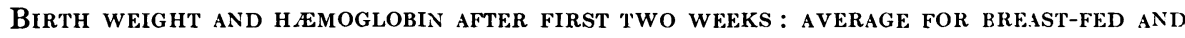
ARTIFICIALLY-FED BABIES COMBINED.

\begin{tabular}{|c|c|c|c|c|c|c|}
\hline Birth weight. & $\frac{1}{2}-1$ & onth & 1-2 months & 2-3 months & 5-6 months & 10-11 mths. \\
\hline 3 lb. odd & & & $62.0 \quad$ (1) & $51 \cdot 0 \quad$ (1) & $64 \cdot 0 \quad(1)$ & $49.0 \quad$ (1) \\
\hline lb. ,, & & & $73 \cdot 0$ & $58 \cdot 3 \quad(4)$ & $61 \cdot 9 \quad(6)$ & $48 \cdot 4 \quad(3)$ \\
\hline lb. & 109 & (2) & $78 \cdot 1$ (11) & $689 \quad(22)$ & $75 \cdot 5(20)$ & $65.8 \quad(7)$ \\
\hline $6 \mathrm{lb}$. & $105 \cdot \varepsilon$ & (9) & $83 \cdot 2(32)$ & $71 \cdot 9$ & $75 \cdot 1 \quad(39)$ & $\pi 1 \cdot 7(25)$ \\
\hline $7 \mathrm{lb}$. & 105.2 & (12) & $81 \cdot 0 \quad(35)$ & $73 \cdot 6 \quad(38)$ & $78 \cdot 1 \quad(51)$ & $74 \cdot 7 \quad(31)$ \\
\hline $8 \mathrm{lb}$. and upwards & 105 & (8) & $84.8(27)$ & $73 \cdot 8 \quad(55)$ & $79 \cdot 4 \quad(42)$ & $72 \cdot 2 \quad(36)$ \\
\hline
\end{tabular}

Figures in brackets indicate the number cf babies examined.

TABLE 3.

BIRTH WEIGHT AND DROP IN HAMOGLOBIN BETWEEN BIRTH AND LATER INFANCY.

\begin{tabular}{|c|c|c|c|c|c|c|}
\hline \multirow{2}{*}{ Birth weight } & \multirow{2}{*}{$\begin{array}{l}\text { Hæmoglobin } \\
\text { at birth }\end{array}$} & \multicolumn{5}{|c|}{ Drop in hæmoglobin percentage at various months. } \\
\hline & & $\frac{1}{2}-1 \mathrm{~m}$. & 1-2 m. & $\mathbf{2 - 3} \mathrm{m}$ & $5-6 \mathrm{~m}$. & 10-11 m. \\
\hline 5 lb. odd $\ldots$ & $153 \cdot 5$ & $49 \cdot 4$ & $80 \cdot 4$ & $89 \cdot 6$ & $83 \cdot 0$ & $92 \cdot 7$ \\
\hline $6 \mathrm{lb} . \quad, \quad \ldots$ & $148 \cdot 2$ & $42 \cdot 4$ & $65 \cdot 0$ & $76 \cdot 3$ & $73 \cdot 1$ & $76 \cdot 5$ \\
\hline $7 \mathrm{lb} . \quad, \quad \cdots$ & $141 \cdot 0$ & $35 \cdot 8$ & $60 \cdot 0$ & $67 \cdot 4$ & $62 \cdot 9$ & $66 \cdot 3$ \\
\hline upwards & $139 \cdot 8$ & $34 \cdot 1$ & $55 \cdot 0$ & $66 \cdot 4$ & $60 \cdot 4$ & $67 \cdot 6$ \\
\hline
\end{tabular}

is well known. Thus babies of low birth weight do not continue to have high hæmoglobin levels; on the contrary, the order is likely to be reversed as compared with that at birth, and by 2 to 3 months old babies of lowest birth weight have the lowest hæmoglobin levels, and the higher the birth weight the higher is likely to be the average hæmoglobin percentage ${ }^{19}$. The low levels usually reached by small premature infants at 2 to 3 months old is shown by Lichtenstein's ${ }^{17}$ average of 40 per cent. hæmoglobin and red cells under $3,000,000$, based on 30 infants; or by Kunckel's ${ }^{15}$ figure of approximately 46 per cent. hæmoglobin for 21 infants whose birth weight averaged $4 \mathrm{lb}$. odd. These figures for the hæmoglobin of premature babies in the third month of life are 27 to 33 per cent. below our figures for the average hæmoglobin value of breast-fed infants at that age.

The cause of THE FALL IN THE FIRST WEeK OF LIFE.-It is generally agreed that the high initial hæmoglobin level at birth is associated with the poor oxygenation of the arterial blood of the fotus in utero, due to the inferiority of the placenta to the lung as a medium for oxygenation and to the mixing of arterial and venous blood. After birth the number of red cells 
is reduced by hæmolysis, and in every baby, whether or not the skin shows the icteric tinge of so-called physiological (hæmolytic) jaundice, there is in the early days of post-natal life a sharp rise in the bilirubin of the blood ${ }^{8,10}$ resulting from the breakdown of corpuscles. This rise reaches its maximum in most babies about the third day ${ }^{10}$ or fourth day ${ }^{18}$; but in infants in whom the rise is high the apex of the curve is reached considerably later ${ }^{10}$. The work of Goldbloom and Gottlieb ${ }^{6,7,8}$ is of interest in this connection. They showed that the sequence of changes in the blood of new-born infants can be reproduced in laboratory animals. They first demonstrated by direct measurement the low oxygen tension of fœtal blood ${ }^{6}$. They next placed guinea pigs in the laboratory under reduced atmospheric pressure ${ }^{\tau}$ and produced in them a reticulocytosis and the expected rise in red cells and in hæmoglobin level, corresponding with the changes in the blood found in persons becoming acclimatized to high altitudes. They then increased the atmospheric pressure to normal, so producing a rise in the oxygen tension of the blood. The result was a rapid fall in the red cells and hæmoglobin which reached normal in five days, and a corresponding rise of bilirubin in the blood, showing that the reduction in red cells was brought about by hæmolysis.

The mechanism of the blood destruction occurring after birth does not appear to be clearly understood. Hampson ${ }^{10}$ has found that in the newborn infant there is a much larger difference between the $\mathrm{pH}$ of the red cell and the $\mathrm{pH}$ of the plasma, than there is in the normal adult. A similar striking difference in $\mathrm{pH}$ is found in certain hæmolytic anæmias', for example, in acholuric family jaundice; and Hampson believes that the chemical mechanism of destruction of the red cells in the new born is connected with this difference in chemical reaction between cells and plasma.

Some of the red cells of the new-born infant are more fragile, that is more easily hæmolyzed in hypotonic saline, than are the cells of a normal adult. The blood of a full-term new-born infant begins to hæmolyze according to Hampson ${ }^{10}$ with a 0.525 per cent. hypotonic saline which causes no hæmolysis of red cells of the normal adult. On the other hand, hæmolysis in both infant and adult is complete in saline of the same strength, i.e., 0.3 per cent. In a premature baby some of the red cells are still more easily hæmolyzed, and in a 14-weeks fœtus hæmolysis began in 0.70 per cent. saline, but was not complete except in saline dilute enough to produce complete hæmolysis in adult blood ${ }^{10}$. At birth, as already mentioned, there are immature erythrocytes in circulation, namely, nucleated red cells and reticulocytes. Goldbloom and Gottlieb ${ }^{8}$ have shown that immature cells are the most easily hæmolyzed in hypotonic saline solution. Premature babies have more of these immature cells in circulation than full-term babies; hence the more rapid the fall in their red cells is presumably, at least in part, the result of the greater proportion of immature cells in their blood.

The possible influence of an anti-hæmolytic hormone in controlling the rapidity of the initial drop in red cells is of considerable interest. Hampson ${ }^{10}$ suggests that the mother's liver may normally provide the fetus with such 
a hormone before the infant's own liver takes on this function, and that physiological jaundice is due to the inefficiency of the liver of the new-born child (a) to provide a secretion preventing hæmolysis, and (b) to excrete the bilirubin. van Creveld and Heybroek ${ }^{30}$ have shown that for equal falls of erythrocytes from birth the icteric index is variable; hence efficiency in the removal of bile substances from the blood evidently varies in the new born. Hampson also suggests that grave familial jaundice of the new born may be due to ' further delay in the assumption of hepatic efficiency,' and that it is a pathological exaggeration of the ordinary physiological (hæmolytic) jaundice. Hampson ${ }^{10,11}$ has demonstrated conclusively that injection of the serum of a normal adult into an infant suffering from this form of jaundice with anæmia will usually cure: hence it seems probable that the adult serum supplies the infant with some factor controlling hæmolysis. Moreover, in one case of familial icterus gravis neonatorum he showed that the fragility curve of the red blood cells was of the infantile type, but showed hæmolysis in excess of the average for the new born; whereas on mixing the infant's cells with adult serum (his own or the mother's), he diminished hæmolysis and obtained a curve which approximated to the adult type. It seems probable that injection of adult blood will also arrest hæmolysis in so-called congenital anæmia of the new born ${ }^{22}$, a condition apparently closely related to familial icterus gravis. Thus there is a good deal of evidence to support his hypothesis of an anti-hæmolytic hormone which normally prevents excessive blood destruction in the new-born child. However, it seems the problem cannot yet be considered definitely settled, since Goldbloom and Gottliebs have been unable to demonstrate any anti-hæmolytic agent in the mother's blood when her serum is added to the washed corpuscles of the infant.

Causes of the fall between one week and three months.-By one week old the more fragile cells in the blood have apparently been destroyed, for by this age the hæmolysis curve of the infant's corpuscles in hypotonic saline approximates to the curve for adult blood ${ }^{8}$. But, as already shown, the red cell and hæmoglobin level continue to fall until about the third month of life and in many cases, especially in babies small at birth, reaches levels so low that they must be considered pathological. Is, then, this continued fall due to continued blood destruction, or is it due to diminished blood production, or to both? Hampson ${ }^{10}$ finds excess of bilirubin in the blood until one month of age, and the figures given by Lucas and his co-workers suggest that in some babies the fall in bilirubin may be slower. Hence excessive blood destruction presumably continues throughout the first month.

For evidence of activity in the blood-forming organs. we may consider the number of reticulocytes in the blood. At birth it is agreed that this is high, but within one or two weeks after birth the number has dropped to a figure approximating to that for adult blood ${ }^{4,2.5}$, and apparently remains fairly stationary until the fourth week. Thereafter, from the fifth to the 
eighth week it rises steadily ${ }^{24}$. van Creveld and Heybroek $^{30}$ find a similar fall and subsequent rise in the reticulocytes of premature babies. This appears to support the view that during the first month of life the rate of blood production is normally much diminished, but that after this time it again increases. Schiff and $\mathrm{Joffe}^{2 \tau}$ give some interesting figures for three premature babies. These babies were treated with copper, but if we assume that copper given alone was without effect on the red cells (and such an assumption seems justified by the work of Josephs ${ }^{13}$ and others), we can regard these as untreated cases. In the first month of life the percentage of reticulocytes in the blood of these infants was 12 to 10 , but between $1 \frac{1}{2}$ to 2 months old it rose as high as 23 to 40 , suggesting that during this time, when in each baby the red cells and hæmoglobin percentages were dropping, the organism was making a great effort to balance this excessive blood destruction. Moreover the following case suggests that if the rate of blood destruction is far in excess of normal during the early weeks of life, blood production will continue from birth onwards, at a high level to make good the excessive destruction. The case was one of icterus gravis neonatorum observed by Ockel ${ }^{2.5}$, and the reticulocytes were maintained at a similar level to that at birth until the eighteenth day when the child died. Similar high reticulocyte counts in icterus gravis are quoted by other authors. Contrast this with the figure for normal babies in whom Friedlander and Wiedemer ${ }^{4}$ find about 14,000 to 28,000 reticulocytes per c.mm. at birth and 0 to 25 by the ninth day. The above findings taken together suggest that (a) the drop in hæmoglobin from birth to about the third month is primarily due to destruction of red cells; but that (b) normally during the first month when the cells are presumably in excess of the body's requirements and hæmolysis is physiological, cell production is diminished; and that (c) after the first month cell production again increases, though it does not usually balance destruction until the third month of life. If, however, in the first weeks of life destruction produces a red-cell level which is pathologically low, increased production comes into play at once.

Trought $^{29}$ has demonstrated an interesting fact about the hæmoglobin of new-born infants. The hæmoglobin of the new born, or a proportion of it, differs in chemical composition from the hæmoglobin of the human adult, and this embryonic type of hæmoglobin continues to be present in the blood until at least $1 \frac{1}{2}$ months of age, and perhaps longer, as her series contained no babies between $1 \frac{1}{2}$ and $4 \frac{1}{2}$ months of age. By $4 \frac{1}{2}$ months all the. hæmoglobin is of the adult type. The significance of this observation is not yet known. It may be that blood destruction continues until the body is rid of the whole of the embryonic hæmoglobin. In favour of this view is the fact that the embryonic hæmoglobin is present during the period after birth when hæmolysis outstrips blood formation: whereas, by $4 \frac{1}{2}$ months old, when the normal red cell building has outstripped destruction, the whole of this embryonic hæmoglobin has been replaced by the adult type. 
It seems unlikely that the drop in red cells in the first two to three months of life is associated with any nutritional deficiency: some writers ${ }^{16}$ have claimed to improve the hæmoglobin level in the second and third months of life by giving iron, but satisfactory proof of this is wanting ${ }^{30}$. Moreover, if iron or any other nutritional deficiency, were a limiting factor at this age, it seems probable that the babies who grown most rapidly would show the most marked deficiency, and hence the lowest hæmoglobin levels. But Dr. Bradford Hill ${ }^{19}$ examining our data, could find no statistical evidence to indicate this, that is he failed to find any correlation between rate of growth (for constant birth weight) and the hæmoglobin level at $2 \frac{1}{3}$ to $3 \frac{1}{3}$ months old. Two other facts which also contra-indicate any theory of iron deficiency are: first, that recent investigations have shown that the iron store in the liver increases up to two months of age ${ }^{5}$ (see next section); and secondly, that if anæmia develops in the first three months of life it is characterized by a reduction in red cells and in hæmoglobin alike ${ }^{17}$, and is not of the chlorotic type usually associated with iron deficiency.

The problem of abnormally low hæmoglobin levels in the first three months of life would be simplified by finding an effective means of prophylaxis. Abt and Reynolds' claim that iron together with a ' secondary anæmia liver extract' (prepared as suggested by Whipple and Robbins) is of prophylactic value in the anæmia of premature babies in the first half year of life; but its effect during the first three months is not established by their published data, and after three months of age we know that iron alone begins to show its prophylactic value in some infants (Graph II).

It is evident that further information about the drop in hæmoglobin level in the first three months of life is required. This might be obtained by studying the possible prophylactic value of injections of adult blood. Such an investigation is now being carried out.

Rise between the third and sixth month.-Whatever factors may control the rapid diminution in red cells in the early weeks of life, they are usually checked at two or three months of age; and even in premature infants and small twins (Graph I, Cases 3 and 4), from about this age redcell formation outstrips destruction and more than keeps pace with the growth of the infant. Thus from about the third to the sixth month there is, in nearly every infant, a rise in the hæmoglobin level and a proportionately greater rise in the red-cell count. Lichtenstein' ${ }^{17}$ series of premature babies showed between the third and sixth months an average rise of nearly two million in the red cells, and by six months old they were suffering from an anæmia of the chlorotic type because red-cell formation had outstripped hæmoglobin formation.

In this connection the work of Gladstones is of great interest. He found that from two weeks to two months of age there is an accumulation of iron in the infant liver and spleen over and above the store present at birth, but 
after this age the excess diminishes and by four months of age has disappeared. The inference seems clear. The infant organism has been conserving from the early weeks of life iron and possibly other products of the breakdown of corpuscles, and as soon as the causes producing a fall in hæmoglobin level are checked, this iron is steadily transferred from the depots in liver and spleen to the new red-blood corpuscles which are being put into circulation, and somewhere round the third month the hæmoglobin level begins to mount. By four months of age, however, the obvious excess of iron has disappeared from the liver, and since the infant's diet, namely milk, is very poor in iron a deficiency of this substance is likely to occur with a consequent check in the rise of the hæmoglobin level soon after the store has given out. Sometimes the need for extra iron occurs as early as three months, for iron treatment begun under two months will produce in the fourth month a higher average hæmoglobin level than is found in untreated babies (Graph II). Iron administration will in many infants accelerate and increase the rise ordinarily occurring without treatment after the third month, and with such treatment a rise of over 30 per cent. may sometimes occur in one month (Graph II, Case 5).

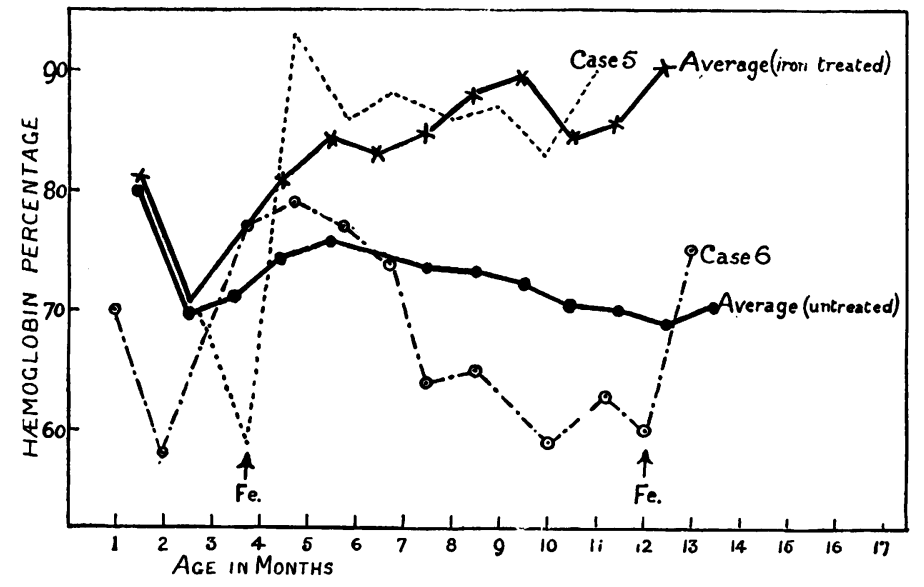

GraPH II.-Average hæmoglobin curves for artificially-fed babies for the first year of life: (a) untreated, and (b) treated with iron from under 2 months old; with (c) hæmoglobin curves Cases 5 and 6.

CASE 5.-Full-term baby given iron from $3 \frac{3}{1}$ months when his hæmoglobin was $59 \%$. The iron presumably accelerated the expected rise since there was subsequently a rise of $34 \%$ in 4 weeks, and the hæmoglobin thereafter remained near $86 \%$ as a result of continuous iron treatment.

Case 6.-A full-term baby showing a rise of $21 \%$ between 2 and $4 \frac{3}{2}$ months old without treatment, and thereafter a fairly steady fall till 10 months old. The fall was arrested between 10 and 12 months old, presumably as a result of a mixed diet, and the administration of an iron salt at 12 months of age caused a sharp rise.

The fall in hæmoglobin after five months. - Without iron treatment the initial rise is usually followed at about six months of age by a slow fall in hæmoglobin level (Graph I), which continues until iron is supplied to the 
baby (Graph II, Case 6). On the other hand, with regular iron treatment the hæmoglobin level can be kept in the neighbourhood of 86 per cent. provided the child is not ill (Graph II, Case 5). If the baby has grown quickly relative to its birth weight, if, for instance, this has been trebled instead of doubled by five or six months of age, then its iron store is exhausted earlier. By the statistical analysis of our figures for breast-fed babies, Dr. Bradford Hill ${ }^{19}$ has shown that from 6 to 12 months old the hæmoglobin level is correlated with the rate of growth; babies who have made the largest percentage increase in weight over their birth weight tend to have the lowest hæmoglobin levels. Rapid growth together with presumably excessive hæmolysis in the first two months of life are almost certainly the main causes predisposing to nutritional anæmia in babies small at birth; they grow relatively faster than babies of higher birth weight, and consequently exhaust their iron store earlier, and so may show the effects of iron deficiency from any age after about three months. Ante-natal iron deficiency in the mother is another cause of early exhaustion of the iron store in the infant, with consequent anæmia ${ }^{28}$.

So far no account has been taken of the possible part played by copper and other mineral or organic deficiencies in this common nutritional anæmia of babies. This must not be taken to imply that iron is always the only deficiency, but, as shown in another paper ${ }^{21}$, there are reasons for supposing that copper deficiency is seldom present in the nutritional anæmia in babies. The fact that large doses of inorganic iron, far in excess of the amount utilized by the baby, are desirable in treatment, is apparently due to deficient absorption ${ }^{12}$.

This is not the place to discuss the relatively uncommon type of nutritional anæmia due to deficiency of vitamin $\mathbf{C}$, nor of the forms of anæmia, probably partly nutritional in origin, which may arise as a result of lesions affecting the digestive tract, nor again of the anæmia associated with deficiency of internal secretion from the thyroid gland; but, of course, any of these may occur in infancy and complicate the picture already described.

The rise in hæmoglobin on a mixed diet.- In our study of nutritional anæmia in infancy we found that towards the end of the first year of life a certain number of infants showed a slow and usually irregular rise in their hæmoglobin level. This is evidently due to their receiving a mixed diet and thus considerably increasing their iron intake. It is worth noting, however, that the rise in hæmoglobin level on an ordinary mixed diet is often delayed, and is, moreover, greatly inferior to that usually obtained by giving an inorganic iron salt ${ }^{19}$.

Elvehjem $^{3}$ has drawn attention to the inferiority of organic iron to inorganic iron in the treatment of ' milk anæmia' in the rat, and this accords with our general observations in children. On the other hand, 
treatment with liberal amounts of liver may produce very good results ${ }^{19}$, though the amount of iron supplied is only a fraction of that ordinarily prescribed in the form of a drug. This may indicate that liver supplies some other factor which augments the effect of the iron it contains, or it may simply mean that iron present in liver is in an easily utilizable form.

\section{Conclusions.}

An attempt has been made from the data available to relate the usual variations in hæmoglobin level during the first year of life to their causal factors. Some of the conclusions are tentative, but the suggested hypotheses may serve to stimulate further investigation.

The high hæmoglobin level of the new-born infant is known to be related to the low oxygen tension of the blood of the fœtus in utero ${ }^{7}$ and its consequent need of a relatively greater amount of hæmoglobin. Hæmolysis of red cells apparently exceeds red-cell formation during late intra-uterine life, as shown by the presence in the new-born infant's blood of bilirubin considerably in excess of adult figures ${ }^{8,}{ }^{10}$; and the fact that infants larger, and presumably more mature, at birth tend to show on the first day of life lower hæmoglobin percentages in their blood than do smaller infants. Increasing the oxygen tension of the blood has been shown to produce in animals a drop in red-blood cells with a rise in bilirubin ${ }^{7}$, which suggests that this intra-uterine hæmolysis may run parallel with improving oxygenation of the fœtal blood during the latter part of intra-uterine life. 'The rate of red blood cell production presumably decreases during the latter part of fœtal life since reticulocytosis diminishes towards term ${ }^{25}$.

After birth there is a fairly rapid destruction of red cells, the more fragile immature cells ${ }^{8}$ which are present in greater proportion in the blood of immature infants, being early destroyed. Hence there is a rapid fall in hæmoglobin in the first week of life, greatest in infants of low birth weight, and less in infants of higher birth weight. This destruction causes a further increase in blood bilirubin ${ }^{10},{ }^{17}$, and may give rise to an icteric tinge to the skin, namely ' physiological' jaundice. During this stage of physiological blood destruction, red-cell building is presumably decreased as shown by the small number of retioculocytes in the blood of normal infants between one and four weeks old ${ }^{24}$. The drop in red cells continues until about the third month of life. The meagre evidence available seems to point to redcell building again increasing between five and eight weeks old, though it does not usually exceed destruction till the third or fourth month. Red-cell hæmolysis of a pathological grade in the first weeks of life may call out a counteracting increase in red-cell production.

If we neglect cases of icterus gravis neonatorum, and the severe hæmolytic anæmia of the new born which is probably closely related to it, no effective method of treatment has yet been found to check an excessive 
drop in hæmoglobin level between birth and two or three months of age, e.g., a drop to less than 50 per cent., such as may not infrequently be seen in premature infants.

Iron derived from hæmolysis of red cells in the early weeks of life augments the original store present in the liver and spleen at birth ${ }^{5}$, and is utilized during the period of a rising hæmoglobin level, namely between about the third and sixth month of life. This store, however, quickly becomes depleted, especially in infants whose rate of growth has been rapid; and consequent iron deficiency often retards the rise and usually causes a slow drop in hæmoglobin level after the sixth month of life. Towards the end of the first year of life a slow spontaneous rise in hæmoglobin level may again occur, resulting from increased iron intake due to a mixed diet.

The author offers her thanks to the Medical Research Council for a personal grant which allowed her to carry out her investigations. She is also much indebted to Miss Lorel Goodfellow for her constant help.

Postscript.-Since this paper was written Professor L. G. Parsons and his colleagues have published their important studies in anæmia in this journal, and have had under consideration many of the points discussed in the present paper. Nevertheless it is hoped that the present survey may prove useful and may supplement in certain respects the valuable papers from the Birmingham Children's Hospital.

H.M.M.M.

\section{REFERENCES.}

1. Abt, A. F., \& Reynolds, N. B., J. Am. Med. Ass., Chicago, 1932, XCVIII, 2270.

2. Baar, H., \& Stransky, E., Die klin. Hämatol. d. Kind., Leipzig, 1928, 9.

3. Elvehjem, C. A., J. Am. Med. Ass., Chicago, 1932, XCVIII, 1047.

4. Friedlander, A., \& Wiedemer, C., Am. J. Dis. Child., Chic., 1925, XXX, 804.

5. Gladstone, S. A., Ibid., 1932, XLIV, 81.

6. Goldbloom, A., \& Gottlieb, R., J. Clin. Invest., N.Y., 1930, IX, 139.

7. Goldbloom, A., \& Gottlieb, R., Ibid., 1930, VIII, 375.

8. Goldbloom, A., \& Gottlieb, R., Am. J. Dis. Child., Chic., 1929, XXXVIII, 57.

9. Hampson, A. C., \& Maizels, M., J. Physiol., Cambridge, 1927-8, LXIV, (Proc. Phys. Soc.), xx.

10. Hampson, A. C., Guy's Hosp. Rep., Lond., 1928, LXXVIII, 199.

11. Hampson, A. C., Lancet, Lond., 1929, I, 429.

12. Heath, C. W., Strauss, M. B., \& Castle, W. B., J. Clin. Invest., N.Y., 1932, XI, 1293.

13. Josephs, H., Bull. Johns Hopkins Hosp., Baltimore, 1931, XLIX, 246.

14. Josephs, H., Ibid., 1932, LI, 185.

15. Kunckel, D., Ztschr. f. Kinderh., Berlin, 1916, XIII, 101.

16. Landé, L., Ibid., 1926, XLII, 349.

17. Lichtenstein, A., Svenska läk.-sällsk., Stockholm, 1917, XLIII, 1824.

18. Lucas, W. P., et al., Am. J. Dis. Child., Chic., 1921, XXII, 525.

19. Mackay, H. M. M., \& Goodfellow, L., Med. Res. Council, Sp. Rep. Ser., Lond., 1931, No. 157.

20. Mackay, H. M. M., Arch. Dis. Childh., Lond., 1933, VIII, 221.

21. Mackay, H. M. M., Loc. cit., 145. 
22. Mackay, H. M. M., Proc. Roy. Soc. Med., Lond., 1933 (in press).

23. Mayers, L. H., Arch. Int. Med., Chicago, 1922, XXX, 478.

24. Ockel, G., Münch. med. Wchnschr., Munich, 1924, LXXI, 1356.

25. Ockel, G., \& Haagen, W. W., Arch. f. Kinderh., Stuttgart, 1927, LXXX, 107.

26. Schiff, E., Jahrb. f. Kinderh., Berlin, 1901, LIV, 1, 172.

27. Schiff, E., \& Joffe, N., Klin. Wchnschr., Berlin, 1931, X, 1946.

28. Strauss, M. B., J. Clin. Invest., N.Y., 1933, XII, 345.

29. Trought, H., Arch. Dis. Childh., Lond., 1932, Vll, 259.

30. van Creveld, S., \& Heybroek, N., Rév. franç. péd., Paris, 1932, VIII, 158.

31. Zibordi, F., Quoted by Baar and Stransky². 